\title{
CONSUMER DECISION PROCESS IN RESTAURANT SELECTION: AN APPLICATION OF THE STYLIZED EKB MODEL
}

\section{PROCES ODLUČIVANJA POTROŠAČA O IZBORU RESTORANA: PRIMJENA STILIZIRANOGA EKB MODELA}

\author{
Market-Tržište \\ Vol. 28, №. 2, 2016, pp. 173-190 \\ UDK 658.89:640.432(410) \\ Preliminary communication
}

\author{
Pedro Longart ${ }^{a}$, Eugenia Wickens ${ }^{b}$, Ali Bakir $^{c}$ \\ a) Universidad de las Americas, Quito, 170137, ECUADOR, pedro.longart@udla.edu.ec \\ b) UUM College of Law, Government and International Studies, Universiti Utara Malaysia, Sintok, MALAYSIA, \\ dreugeniawickens@gmail.com \\ c) Bucks New University, Queen Alexandra Road High Wycombe, HP11 2JZ, UNITED KINGDOM, Ali.Bakir@bucks.ac.uk
}

\begin{abstract}
Purpose - The aim of this paper is to propose a framework based on empirical work for understanding the consumer decision processes involved in the selection of a restaurant for leisure meals.
\end{abstract}

Design/Methodology/Approach - An interpretive approach is taken in order to understand the intricacies of the process and the various stages in the process. Six focus group interviews with consumers of various ages and occupations in the South East of the United Kingdom were conducted.

Findings and implications - The stylized EKB model of the consumer decision process (Tuan-Pham \& Higgins, 2005) was used as a framework for developing different stages of the process. Two distinct parts of the process were identified. Occasion was found to be critical to the stage of problem recognition. In terms of evaluation of alternatives and, in particular, sensitivity to evaluative content, the research indicates that the regulatory focus theory of Tuan-Pham and Higgins (2005) applies to the decision of selecting a restaurant.

Limitations - It is acknowledged that this exploratory study is based on a small sample in a single geographical area.

\section{Sažetak}

Svrha - Cilj rada je temeljem empirijskog istraživanja predložiti okvir za razumijevanje procesa odlučivanja potrošača pri izboru restorana za obrok u slobodno vrijeme.

Metodološki pristup - Korišten je interpretacijski pristup u svrhu razumijevanja složenosti procesa i različitih faza u tom procesu. Provedeno je istraživanje putem šest fokus grupa s potrošačima različitih dobi i zanimanja u jugoistočnom dijelu Ujedinjenog Kraljevstva.

Rezultati i implikacije - Korišten je stilizirani EKB model procesa odlučivanja potrošača (Tuan-Pham i Higgins, 2005) kao okvir za razvoj različitih faza procesa. Identificirana su dva različita dijela procesa. Otkriveno je da je za fazu prepoznavanja problema ključna prigoda. Kod procjene alternativa, a posebno kod osjetljivosti procjenjivanog sadržaja, istraživanje pokazuje kako je teorija fokusa regulacije (regulatory focus theory) Tuan-Phama i Higginsa (2005) primjenjiva na odlučivanje pri izboru restorana.

Ograničenja - Eksplorativno istraživanje ograničeno je na mali uzorak jednog zemljopisnog područja.

Doprinos - Rad predstavlja prvu primjenu stiliziranoga EKB modela koja uzima u obzir motivacijske dimenzije 
Originality - The paper is the first application of the stylized EKB model, which takes into account the motivational dimensions of consumer decision making, missing in other models. It concludes that it may have broader applications to other research contexts.

Keywords - restaurant marketing, consumer decision process, consumer decision making, information processing theory, regulatory focus theory odlučivanja potrošača koje nedostaju u drugim modelima. Zaključno, model može imati širu primjenu u drugim istraživačkim kontekstima.

Ključne riječi - marketing restorana, proces odlučivanja potrošač, potrošačev proces donošenja odluke, teorija procesuiranja informacija, teorija fokusa regulacije 


\section{INTRODUCTION}

Wilkie (1994) claimed that a great deal of the cognitive and physical effort for purchasing products ensue before the actual buying behavior. Thus, it is relevant to understand how consumers are influenced in the pre-purchase stage (Chen \& Dubinsky, 2003). In restaurant settings, this seems a challenging task since the restaurant industry is largely fragmented and formed by different types of establishments. Nonetheless, the purpose of consumers to eat out in a restaurant can be divided into two main purposes. People eat out either for convenience, e.g. a meal during the lunch break, or for leisure. The latter is a more deliberate and thoughtful decision. Sparks, Bradley and Callan (1997) implied that eating out was a high involvement purchase and that restaurants needed highly perceptive employees. Indeed, consumer involvement has been deemed an important factor with considerable influence on consumers' purchase decisions. High-involvement consumers tend to actively gather and disseminate information on products or services that they are interested in, whereas low-involvement consumers do not (Hong, 2015).

Consumer research can be approached from a cognitive perspective in which the consumer shows mainly a rational behavior. Within the cognitive paradigm, consumer research can be divided into three areas: information processing, consumer culture theory, and behavioral decision research (Bartels \& Johnson, 2015).

Consumer culture theory (CCT) seems appropriate mainly for interpretive studies focusing on social and cultural processes, mainly through an interpretivist lens. CCT is akin to the postmodernist rejection of disciplinary boundaries, and to an eclectic approach which accepts contrasting theories (Firat \& Venkatesh, 1995). Nonetheless, Warde (2014, p. 283) criticized the notion of CCT as a constituent of the cognitive paradigm. In this view, CCT is part of a cultural analysis of consumption that implies "that conscious and intentional decisions steer consumption behavior and explain its sense and direction".

Behavioral decision theory (BDT) has a broad psychological context, including aspects such as attention, memory, cognitive representations, conflict, learning, and feedback (Einhorn \& Hogarth, 1981, p. 83). BDT looks more into the aspect of choice than the process as a whole. On the other hand, BDT complements other studies of consumer behavior as it encompasses both normative analyses and descriptive research (Krishnamurti et al., 2012). A normative model is one that describes what rational consumers should do whereas descriptive theories attempt to predict what they actually do (Thaler, 1980).

Information-processing models have made possible the integration of human memory, judgment and decision making into a single framework (Krishna \& Schwartz, 2014). Likewise, information-processing models focus on the interplay of affective and motivational processes on cognitive activity and cover the whole process, with extensive development (Johar, Maheswaran \& Peracchio, 2006). Several models in information-processing theory have been developed, and labeled as "analytical" models by Bray (2008). One of these major comprehensive models is the EKB model (Engel, Kollat \& Blackwell, 1973). This model traces the psychological state of individual purchasers from the point at which they become aware of the possibility of satisfying a material need by purchasing and consuming a product up to their final evaluation of that consumption. Current consumer decision process models, such as the EKB model, are based on a sequence of activities with some limitations in terms of the theoretical background that inspires these models (Erasmus, Boshoff \& Rousseau, 2001; Pankajakshi \& Savitha-Rani, 2015). For example, Tuan Pham and Higgins (2005) highlighted that the EKB model does not address the motivational aspect of the decision-making process (a fundamental limitation of the original model). Despite criticisms and limitations, information-processing models (i.e. the EKB model) have facilitat-

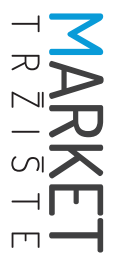


ed great advances in psychological research (Krishna \& Schwartz, 2014). Also, the EKB model "is still firmly embedded as a cornerstone of consumer decision making and is not likely to be jettisoned anytime soon" (Ashman, Solomon \& Wolny, 2015, p. 129). Other consumer decision processes, such as those in the Nicosia model (1966) and Howard and Sheth (1969) model, present serious shortcomings. The Nicosia model focuses on the marketer's perspective, defining consumer activities in very broad terms. The Howard and Sheth model becomes too complex, and its operationalization is fraught with considerable difficulties (Milner \& Rosenstreich, 2013). The popularity of the EKB model is evidenced by its application in recent studies. A refined search in Google Scholar starting in 2012 resulted in 2,210 hits. This paper proposes the application of a modified version of the EKB model - the stylized EKB model (Tuan-Pham \& Higgins, 2005). This model incorporates the motivational perspective to the predominantly cognitive standpoint of the EKB model; for this reason, its application is proposed in this paper in the context of the selection of a restaurant. Understanding the processes involved entails a substantial endeavor, prompting the humble admission that it cannot be achieved in just one paper. Nonetheless, the research aims at providing a road map for this understanding, so aspects like making the final choice and postchoice processes are beyond the scope of this research but are acknowledged to be part of the consumer decision-making effort.

\section{LITERATURE REVIEW}

The literature review will examine models for understanding consumer decision making, as well as approaches used in the context of restaurants and factors influencing consumer behavior.

\subsection{Understanding consumer decision making}

The EKB model was developed by Engel, Kollat and Blackwell in 1973 (Figure 1). The model rep- resents "a road map of consumers that marketers and managers can use to help guide product mix, communication, and sales strategies" (Blackwell, Miniard \& Engel, 2006, p. 70).

\section{FIGURE 1: EKB Consumer Decision Process Model}

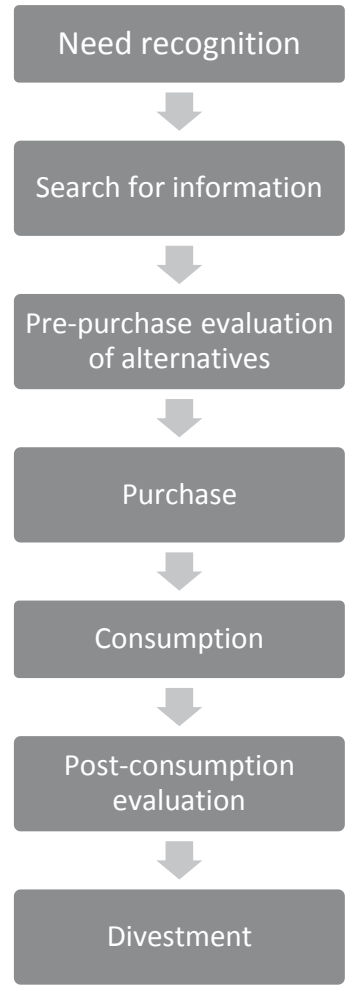

Source: Blackwell, R. D., Miniard, P. W., \& Engel, J. F. (2006). Consumer Behavior, $10^{\text {th }}$ ed. Mason, $\mathrm{OH}$ : Thomson

Tuan-Pham and Higgins (2005) pointed out that our understanding of consumer decision making, which has historically been dominated by the information processing theory and more recently by behavioral decision research, is inadequate. These authors acknowledge that, whilst these two perspectives have offered important insights into the cognitive processes underlying consumers' decisions, they are nevertheless limited. They argued that the motivational dimension of consumer decision making is missing in those perspectives, and that decisions take place in the context of: goals that consumers are pursuing, needs that they seek to fulfill, 
and drives that color their thoughts. They developed Higgins' (1997; 1998; 2002) "regulatory focus theory" of motivation, which has been gaining prominence in consumer research as a theory more suited to understanding consumer decision making.

This theory draws a fundamental distinction between two modes of self-regulation in consumer decision making: promotion and prevention. For this theory, motivation is generally conceived as being driven by the approach of pleasure and the avoidance of pain - basic idea of the hedonic principle. According to Tuan-Pham and Higgins (2005), there are three different perspectives to this theory:

a) The principle of regulatory anticipation: motivation arises from people's expectations or anticipations about the outcomes of their actions. The standard economic theory of choice models choice as a function of expected utility, as formulated from the principle of regulatory anticipation.

b) The principle of regulatory reference: this uses a point of reference in terms of what the desired state is.

c) The principle of regulatory focus theory is conceptualized in terms of strategic means for self-regulation. The means can be approach-oriented (promotion-focused) or avoidance-oriented (prevention-focused). This appears to be linked with a healthy lifestyle since consumers consciously avoid non-healthy options. Jasinka, Ramamoorthy and Crew (2011) called this self-control which, as a key aspect of adaptive decision making, allows the consumer to pursue the deliberate goal to be healthy by overcoming more automatic and immediate-stimulus tendencies, such as the cravings for a particular type of food, that conflict with the goal of being healthy.

Tuan-Pham and Higgins (2005) proposed a stylized model of consumer decision making based on the one proposed by Engel and others (1973) (Figure 2). The application of regulatory focus theory entails a new perspective to the information processing approach.

\section{FIGURE 2: Stylized EKB model}

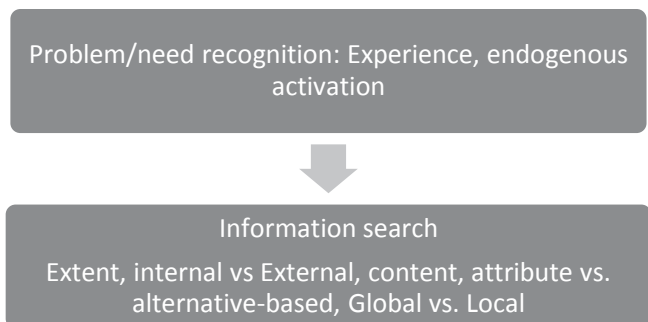

Consideration set formation

Size, composition, criteria order, construction process

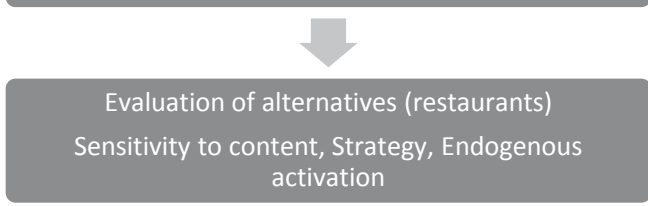

Choice

Rules, Status Quo/Default/Deferral, Risk-Taking Context Effects/Variety-seeking

\section{Post-choice Processes}

Satisfaction/Dissatisfaction Intensity, Emotional

Responses, Dissonance/Regret, Process Satisfaction

Source: Tuan-Pham, M., \& Higgins, E. T. (2005) Promotion and prevention in consumer decision making - the state of the art and theoretical propositions. In: S. Ratneshwar \& D. G. Mick (eds.). Inside Consumption - Consumer motives, goals and desires. Abingdon, NY: Routledge.

As for the first stage, Bruner and Pomazal (1988, p. 56) highlighted that "a consumer problem cannot be adequately addressed until it is properly delineated". Problem (or need) recognition is a crucial stage and is differentiated between an actual state (looking for a restaurant for leisure) and desired state (finding a restaurant that satisfied the need of the restaurant goers) with aspects affecting either the desired and/or the actual state. As for the second stage, there are 
several aspects of information search (Bettman, 1979; Hoyer \& Maclnnis, 2003). These are: extensiveness of the search, direction (internal or external), type of information searched and the structure of the search (alternative-based vs. attribute-based). Consumers then have to simplify the way they make decisions with a consider-then-choose decision process (Hauser, 2014). The third stage is about narrowing down the available set of options, starting with a consideration set. The evaluation of alternatives (fourth stage) refers to an examination of attributes in order to make summary evaluations. Once the alternatives have been evaluated, then the fifth stage (choice) starts. This stage deals with the aspect of decision rules, options taken (status quo, default or deferral), attitude towards risk and preference for variety. The last stage is about a post-choice assessment of the decision.

Many studies have criticized the consumer decision model. Olshavsky and Granbois (1979) pointed out that many purchases, such as in the case of consumer goods, are quick and an elaborate decision-making process may never occur. Rickwood and White (2009) argued that the EKB model is more suited to the purchasing of goods. Fisk (1981) argued that this process is not a linear one as in the EKB model, but one that entails a multiplicity of factors and activities. Nonetheless, although it can be agreed that linear processes rarely occur in reality, it is also important to simplify the process so as to provide a guide to how the process occurs.

Khan, Dhar and Wertenbroch (2005) pointed out that consumers are often faced with choices that are at least partly driven by emotional desires, rather than cold cognitive deliberations. Kahneman (1991) lamented that much of the pioneering work in behavioral decision theory has largely focused on the cognitive aspects of decision making without exploring its emotional dimensions. Although Loewenstein and Lerner (2003) claimed that there was a significant increase in interest in the role of decision making, the bemoaning of Kahneman (1991) seems current as the field of emotion research is still underdeveloped (Lerner, Li, Valdesolo \& Kassam, 2015).

Concerning emotions, another debated issue is whether cognition precedes emotion. Some analysts have cast doubt on the principle of rational, cognitive action by providing examples of what appears to be non-rational behavior. Zajonc (1980) explains that in a typical information-processing model of affect the higher order encoding leads to a cognitive representation of stimulus, which turns into an affective reaction influencing judgment. Zajonc's (1984) argued that affect can be aroused without the influence of cognitive processes and that affect had primacy over cognition. O'Shaughnessy (2003) posited that emotion is always a factor in decision making and that rationality will always be invaded by emotional influences. O'Shaughnessy also claims that there is too much inter-dependence between the cognitive and the affective for a division to be possible. Nonetheless, some authors maintain that the cognitive approach does not preclude emotions. Soscia (2007, p. 874) went further by saying: "research has supported the cognitive approach to emotions by demonstrating strong relationships between emotions and cognitive appraisals structure". The cognitive appraisal approach (Watson \& Spence, 2007; Johnson \& Stewart, 2005; Bagozzi, Gopinath \& Nyer, 1999) is also based on the notion that emotions can be cognitively reconstructed (Smith \& Ellsworth, 1985), and require prior cognitive processing (Alonso-Lopez, 2016). Granovetter (1985) supported the notion that economic action such as purchasing is "embedded" in social relations. Granovetter provided a compelling argument for the need to research consumer behavior pragmatically: "whilst the assumption of rational action must be problematic, it is a good working hypothesis that should not be abandoned. What looks to the analyst like non-rational behavior may be quite sensible when situational constraints, especially those of embeddedness are fully appreciated" (p. 504). 


\subsection{Consumer decision processes in the context of selecting a restaurant}

The stylized EKB model provides a guide for approaches and factors influencing consumer behavior in each one of the stages. The need in this context appears to be "Occasion or reason for eating out". Indeed, when recognizing the need for eating out (stage 1 in Figure 2), the occasion for eating out takes prominence here (June \& Smith, 1987; Kivela, 1997; Mehta \& Maniam, 2002). In the model of Tuan Pham and Higgins (2005), endogenous activation seems also relevant as the recognition of the need may be activated by the consumer, i.e. cravings. Another aspect surrounding the problem/need recognition appears to be social risk (Statt, 1997), or the social context (Payne, Bettman \& Johnson, 1993).

In terms of information search, Lutz and Reilly (1974) found that consumers use more sources of information if they perceive risk, that is, the risk that the restaurant would not meet consumer needs. Bei, Chen and Widdows (2004) found more extensive search from online sources and discussion with friends and family for experience products (services), such as restaurants, than for tangible products. Indeed, Longart (2010) highlighted the importance of positive word of mouth (PWOM) in restaurants. However, the impact of negative word of mouth should also be considered. The information content may consist of discussion on subjective items and/or objective items. The search may be based on a particular type of restaurant (alternative-based) or on restaurant attributes, i.e. quality of food. Also, the search may be based on a more global search of media, such as restaurant guides, or on something closer to the consumer, like a local newspaper or a leaflet.

The stage of consideration set formation also needs exploring in terms of how consumers reduce the restaurant set and whether rules are used, as suggested by Davis and Warshaw (1991), while also probing the findings of Hauser and Wernerfelt (1990) in terms of the size of the sets. The criteria order seems to be another factor as the set may be affected by the consideration of attributes.

In terms of the evaluation of alternatives, the regulatory focus theory of Tuan-Pham and Higgins (2005) examines the sensitivity to evaluative content in terms of whether it is promotion-oriented, prevention-oriented, or both. Likewise, it is necessary to probe the strategy for the evaluation of alternatives, either relying or heuristics or using more systematic methods of evaluation.

\section{METHODOLOGY}

This research is an exploratory study of the Consumer Decision Process when selecting a restaurant for leisure meals. Exploratory research is interpretive in nature, and in this case the exploration is achieved by conducting semi-structured interviews with consumers. This entails a greater degree of flexibility (Bryman, 2008). Bristol and Fern (1996) discovered evidence that participants in groups find the experience more stimulating than do participants in either self-administered surveys with open-ended questions or in structured group interviews, in which interaction is limited. The latter point moves the balance of the argument towards the appropriateness of group interviews to achieve the research aim. The reason is that the nature of the decision of eating out involves the encouragement of discussion and active participation.

Group interviews can take the form of focus groups. The basic underpinning of focus groups is that, by having a group of individuals together and inducing a topic of discussion towards collective attitudes and beliefs of the participants, a dynamic transmission of ideas will start and will result in yielding untapped responses and meaningful information (Threlfall, 1999).

This study took very seriously the aspect of sampling which is very debatable in qualitative studies. This paper follows the recommenda- 
tions of Marshall (1996) for qualitative sampling. Marshall asserted that qualitative sampling should be flexible and pragmatic, where the appropriate sample size is that which adequately answers the research question. This is operationalized with reaching data saturation. Data saturation is deemed to be concerned with the degree to which any new knowledge does not provide new insights, with excess data being the problem for reaching conclusions (Strauss \& Corbin, 1998). In this case, it was considered that if no new key aspects of the Consumer Decision Process emerged from the data, then the data collection process would stop. Six focus groups (4-6 respondents) were selected: three groups of six, two groups of five, one group of four, following the recommendations of Fern (1982). Although these are considered mini-groups (Greenbaum, 1998), this number was sufficient for the purpose of the study (Morgan, 1996). These focus groups were conducted in the South-East of the United Kingdom (London and vicinity). London is one of the most vibrant places in the world for eating out, with people living in the city and their surroundings being attracted to such a varied eating out space. The focus groups followed a semi-structured pattern using an interview guide as the basis for prompting initial questions. The starting question was about the last times that they had selected a restaurant and the process of selecting it. More specific questions followed, such as how they found information about the restaurants, how many restaurants they considered and how they chose the restaurants to be considered, as well as the criteria for considering them.

The respondents were qualified under the criteria that they have eaten out in restaurants for leisure at least twice in the last year and that they have been involved in the decision to select the restaurant. This is deemed to be a convenience sample (Marshall, 1996) looking at people with different backgrounds, ethnicity, gender, occupations, place of residence. Hence, groups were formed by respondents of various occupations, of different ages, ranging from the mid-20s to the mid-60s, and of various ethnic groups (European, Asian, African, and North and South American). Typically, authors state several minimum sample sizes for qualitative studies. Bertaux (1981) stated 15 as a minimum while Green and Thorogood (2004) required a minimum of 20. Hence, the final number of respondents (32) is deemed to be within the acceptable range of size for this type of studies.

The focus group interviews took around 45 minutes on average. The interviews were recorded using an Ipad(C). The data was then organized using qualitative data analysis software (QDAS). The software of choice for this purpose was Nvivo because it is increasingly flexible in adapting to the demands of modern research (Bazeley \& Jackson, 2013).

The research followed Ritchie, Lewis, McNaughton-Nicholls and Ormston's (2014) framework for analyzing data that started with familiarization with the data. This process of data management began in the literature review and was followed by looking at the interview transcripts. Then an initial thematic framework - the stylized EKB model (Tuan-Pham \& Higgins, 2005) - was used. The model refers to problem recognition, information search, consideration set formation, evaluation of alternatives, and choice. Most econometric methods for studying choice start with the stages of evaluation of alternatives and then the choice stage in the stylized EKB model $\left(4^{\text {th }}\right.$ and $5^{\text {th }}$ stages, see Figure 2$)$. For instance, in quantitative models like conjoint analysis, evaluation of alternatives such as the potential evaluation of different product concepts are part of this stage, whereas the choice stage refers to choosing several concepts from a previous stage of evaluation (within the same survey). Hence, it is believed that the first three stages should be considered before the application of econometric models, and for this reason, they will be titled "antecedents to the decision" (Figure 3). The other two, normally part of quantitative research, i.e. econometric models like conjoint analysis, will be titled "choice considerations" (Figure 4). The elicitation of other 
themes followed the structural approach (DiCicco-Bloom \& Crabtree, 2006), in which the EKB model serves as a template and emerging themes are then allocated within the structure.

FIGURE 3: Stages of the Consumer Decision Process: antecedents

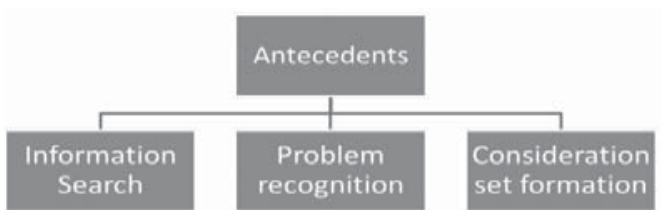

FIGURE 4: Stages of the Consumer Decision Process: choice considerations

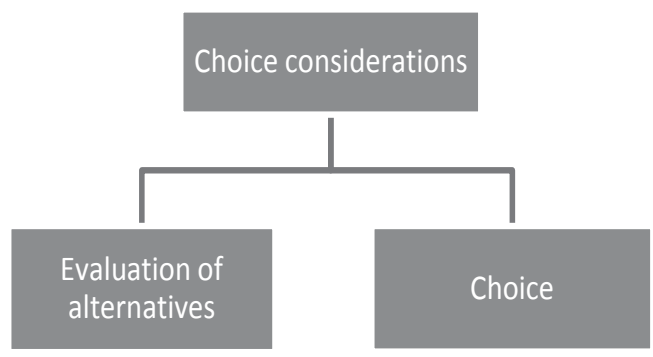

\section{FINDINGS}

\subsection{Problem/need recognition}

The aspects considered as relevant to how the consumers state their problem (or need) include: the occasion for eating out (e.g. birthday, anniversary) and how the need (for eating out) emerges. In other words, how the problem of selecting a restaurant is framed in the first place.

\subsubsection{The role of occasion for eating out}

The theme of occasion for eating out was repeatedly mentioned across all the interviews by several respondents. For instance: "it depends on what the occasion is. So, if it was a really special occasion, I want to spend lots and lots of money..."

It can be inferred from the data that any decision for selecting a restaurant is most normally preceded by a consideration of the occasion for eating out; therefore, in the EKB model, occasion seems to be a factor affecting either the desired state or actual state, which Bruner and Pomazal (1988) called current situation. The criticality of occasion was discussed by Mehta and Maniam (2002), and Kivela (1997). This centrality of occasion underpinned the study of restaurant attributes by June and Smith (1987).

\subsubsection{Endogenous activation}

Endogenous activation, as part of the stage of problem recognition (Tuan-Pham \& Higgins, 2005), appears to have several facets. A respondent mentioned cravings as a contributor to that activation: "I think sometimes you can almost have sort of a craving...".

Bruner and Pomazal (1988) approached the stage of problem recognition as an arousal of needs affecting the actual state. On the other hand, this is also connected with the second stage of the CDP process in Figure 4, as the evaluation of alternatives can be alternative- based (types of cuisine) or attribute-based (food, ambiance, etc.). Cravings prompt for an alternative-based option, which in this case is the type of cuisine. This means that cravings may lead to alternative-based considerations, prior to attribute-based considerations.

Endogenous activation appears to be related to consumer moods. This is what Belk (1975) called antecedent states. This mood appears to trigger a particular decision, as one respondent put it: "Mood and emotion I mean, the assumption is that the food is going to be good, but the mood and the vibe and....". This confirms that the decision cannot only be viewed from the cognitive perspective, as attributes may be assumed and emotions can take precedence over rational considerations.

Special affections and feelings can be part of that decision-making process. For instance, a respondent referred to the case of the need for an emotional connection: "The only case I could bring up for that kind of emotions is linked to a restaurant called Dans Le Noirs, which is a restaurant for people who are blind ... and I perhaps can

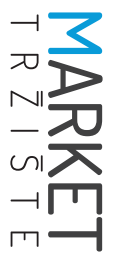$$
\Gamma
$$

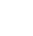


find or have an emotional experience and bond with it".

\subsubsection{Role of companionship}

This theme can be considered from a broader perspective than just the minimization of social risk (Statt, 1997). Indeed, companionship seems to be a critical antecedent to the decision, as eating out in a restaurant is normally a social event. Indeed, respondents saw it as part of the decision dynamics. Also, there are the practical issues of convenience for the social group: "Another consideration is who you are going to dinner with....".

Companionship can also be looked at from a cultural perspective of the group constituents, for instance: "When I go out with the Spaniards and Italians ...". This is the social context that Payne et al. (1993) referred to as group membership. It is a factor affecting the desired state of the problem recognition stage, referred to by Bruner and Pomazal (1988) as reference groups. On the other hand, family as a social group has critical connotations as an antecedent: "My sons love the food there, the lamb is very nice and they usually prefer to go there...".

\subsection{Information search: the role of Positive Word of Mouth (PWOM)}

The research has found that PWOM is particularly important for considering new restaurants in the consideration set: "For me, if it is a new restaurant, the decision is based on recommendation...". Positive WOM may not be the only trigger to the decision but it is definitely an important contributor: "I think normally now the places that you hear through word of mouth are the ones that most influence my decision".

Nonetheless, it was found that WOM has obvious limitations. A respondent acknowledged that the information is basically subjective: "... and everybody's opinion is different...". On the other hand, there is the recall limitation, as put by another respondent: "I don't think word of mouth really works for me because I don't retain the information...".
Negative WOM (NWOM) may be even more important: "If someone said I'm going to whatever and someone said don't go there, I wouldn't go". This confirms previous studies (Bone, 1995; Herr, Kardes \& Kim, 1991; Mizerski, 1982; Wangenheim, 2005) that have found the influence of NWOM to be greater than positive word of mouth.

\subsubsection{Information search: the role of the media}

The role of the media - both printed and online - was also a subject of research. It seems that consumers do consider restaurant guides, like the Good Food guide or the Good Pub guide, in which restaurants are scrutinized. However, although respondents discussed the need for looking for something local, there was no mention of local newspapers, just guides of a wider reach. It also appears that this information consists of both subjective statements, such as the quality of food and objective information, such as price, which leads to pricequality inferences: "And you know the level and service of the food should be good...".

\subsubsection{Consideration set formation}

This aspect may appear concomitant with information search since the extensiveness of search may influence how the consideration set is formed. According to information processing theory, 'the consideration set is formed and used by the consumer for subsequent purchase operations' (Roberts \& Nedungadi, 1995). Davis and Warshaw (1991) suggested that consumers employ screening procedures using non-compensatory rules to reduce the consideration set to a manageable size. Some of the aspects probed or emerging from the research were green consumerism and restaurant etiquette. This raises the question: would some consumers discard restaurants that are not "green"? Likewise, is restaurant etiquette a constraint? And if it is a constraint, should the restaurant be eliminated from the consideration set?

In terms of the consideration set size, it was found that sets are not normally larger than four 
(4) restaurants, with some exceptions for special occasions. That is consistent with the findings of Hauser and Wernerfelt (1990) about sets of 3-7 for a range of products and services. The set composition and number seems to be largely influenced by the type of cuisine preferred, and for some respondents this was the starting point, either to narrow down the number of options or to enable respondents to compose the set on the basis of a particular type of cuisine (i.e. a set of Italian restaurants). Composition of the set is also influenced by word of mouth as new restaurants can form part of the set if a restaurant is recommended.

\subsubsection{Green (ethical/sustainable) consumerism}

Respondents were aware of the issues and the different aspects that come under the umbrella of sustainability and green consumerism. In the first place, respondents referred to the aspect of "food miles" but without it having a major impact on the decision: "For me it (sustainability) wouldn't necessarily come into my decision making".

Local produce is linked to the idea of seasonality: "And they tend to do seasonal things too, I think the thing that you feel better about is when they will say it is local".

Another respondent linked this to organic food: "the type of ingredients they use, if they are organic...". Respondents also connect sustainable restaurants to engaging with a wider concept of corporate social responsibility, particularly, charitable giving: "... And it's giving money back into the local community". Or about the environmental impact as well: "... how are they getting electricity into the restaurant...'

\subsubsection{Restaurant etiquette}

Restrictions such as dress codes in restaurants may play a role prior to selecting a restaurant. Some respondents are against the restrictions: "Restaurants sometimes put up barriers or sometimes you have barriers and think ....".

Nonetheless, some respondents were appreciative of these rules and again stressed the impor- tance of occasion for having these restrictions in place: "You would probably dress differently, you would be in a different mood; you would want to feel like if it was a special occasion".

This aspect seems to be affecting the evaluation of alternatives (second stage of CDP) as this should have been part of the consideration set prior to considering whether to dress up for this particular occasion and restaurant.

\subsubsection{Criteria order}

It was clear that food was mentioned repeatedly as the most important attribute, normally over aspects like ambiance. This confirms the findings of Pantelidis (2010), Clark and Wood (1998), Mehta and Maniam (2002), and Longart (2010). A respondent commented: "If they said to me it's a great atmosphere... well, I don't go to restaurants for atmosphere...".

Three other respondents said: "The food is more important for me than the ambiance"; "The food, I really enjoyed the food, and I'm really interested on how they cooked it"; "So, yes for me I think the food would be a priority".

\subsection{Choice considerations}

After a consideration set is in the mind of the consumer, the next stage is then about making the choice. That is what was termed "Choice Considerations". There are two stages here. The first stage refers to the evaluation of alternatives, which refers to making summary evaluations and can just mean discarding an option very quickly. After that, the stage of deciding which option to take is what is called the choice stage (not examined in this paper).

\subsubsection{Evaluation of alternatives}

In terms of evaluation of alternatives and, in particular, sensitivity to evaluative content, the research seems to indicate that the regulatory focus theory of Tuan-Pham and Higgins (2005) can be applied to the decision of selecting a restaurant. As for promotion-focused self-regulation, a respondent evaluated very positively 
a type of cuisine. Another evaluated positively references to authenticity, and evidence is found for several other attributes. On the other hand, some consumers who have activated prevention seem to evaluate negatively restaurants that they would try to avoid; for example, restaurants with a dress code or those that predominantly serve spicy foods.

In terms of evaluation strategy, Tuan-Pham and Higgins (2005) proposed that promotionfocused respondents rely on heuristic modes of evaluation, whereas preventionfocused respondents use more systematic modes of evaluation. For instance, a promotion-focused respondent evaluated in terms of taste and convenience, that is, about the type of food and whether it is convenient. A respondent who raised the issue of allergies (preventionfocused) was very vocal about several aspects like driving distance, where he would park, and made reference to style, location and price, while also appearing to have a very elaborate process for evaluating restaurants. Hence, these findings confirmed Tuan-Pham and Higgins's (2005) propositions. On the other hand, it seems obvious that states of promotion and prevention can be endogenously activated. The respondent who raised the issue of allergies was also concerned about noisy restaurants. It was noted that the state of prevention (avoiding those restaurants) was endogenously activated by the alternatives.

\section{DISCUSSION AND IMPLICATIONS}

The Consumer Decision Process using the model of Tuan-Pham and Higgins (2005) can be broadly divided into two parts: antecedents and choice considerations (Figure 5).

FIGURE 5: Stages of the stylized EKB Consumer Decision Process model

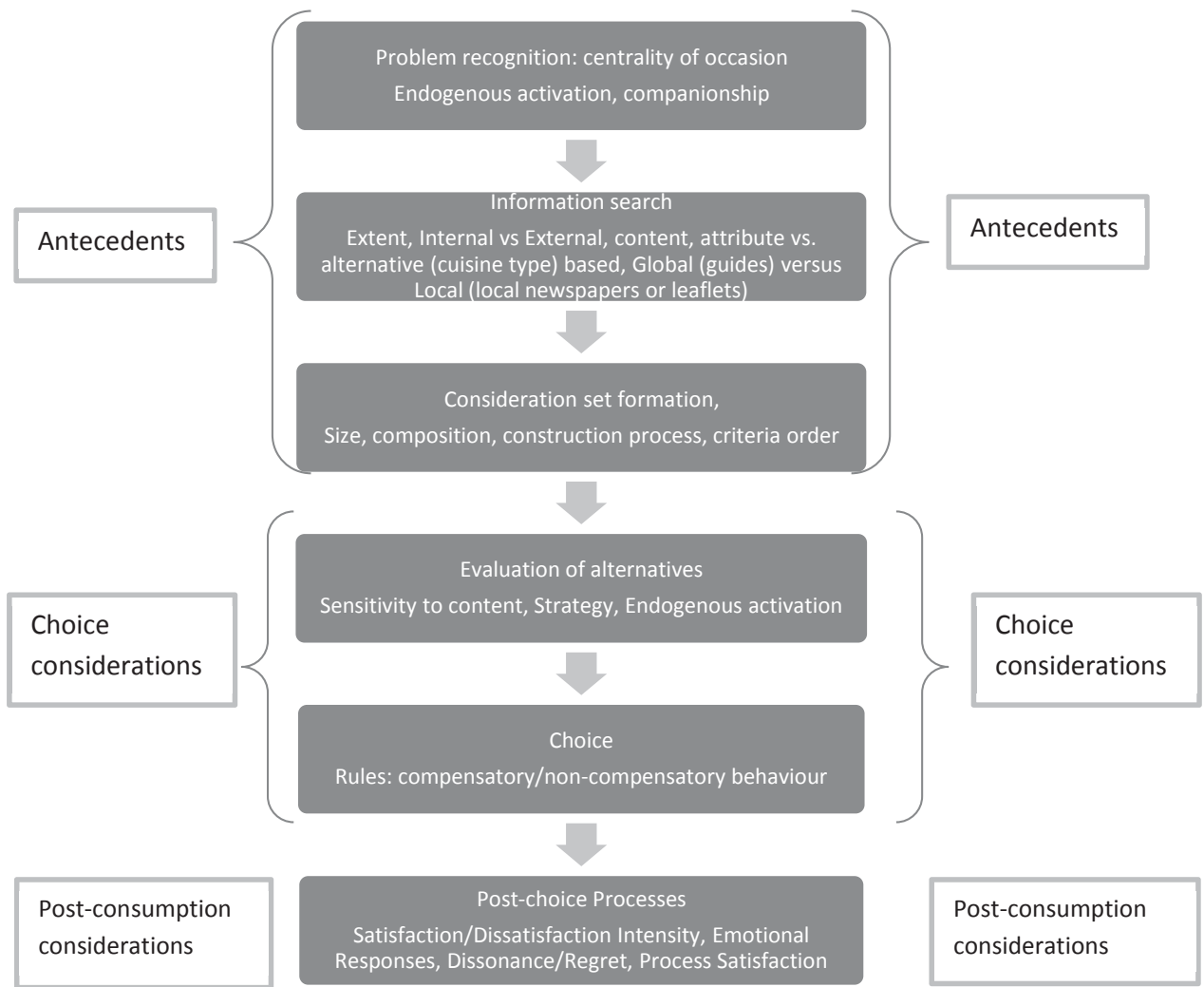


As examined in the literature review, problem/ need recognition is a critical stage. Occasion was found to be central to problem/need recognition, as it seems that the needs of consumers for diverse occasions may differ significantly, pointing towards an appropriate basis for market segmentation. This is deemed to be another key contribution of this research, the suggestion that analysis of the selection should be based on occasion for eating out. It is suggested that any study which looks into the decision-making process for products or services consider primarily the context upon which the decision is made.

Information search appeared to be a debated issue in the research. It was evident that the number of media and the eagerness to talk about restaurants attest to the fact that many restaurant goers engage extensively in information search when looking for a restaurant. Although information can indeed be searched for internally, research shows that it is normally conducted externally, either by looking at the printed media, online reviews or through word of mouth, the latter being particularly important in the restaurant context. The type of information in this case seems to focus either on content that reveals restaurant attributes, or different types of cuisine. The search can be structured by alternative (Type of cuisine), in which consumers can find restaurants listed under a particular type of cuisine in printed or online media, or by attributes. The search is particularly affected by location, and restaurant-goers have to decide whether to search globally (i.e. all of London) or locally. The dimensions considered included: driving distance, convenience for everyone to meet up, vicinity to entertainment area, and public transport available.

In terms of the consideration set size, it was found that sets are not normally larger than four (4) restaurants, with some exceptions for special occasions. The set composition and number seems to be influenced by the type of cuisine preferred, and by word of mouth, since new restaurants can form part of the set if a restau- rant is recommended. Indeed, sets seem to be constructed either by including alternatives through word of mouth or by excluding alternatives, as in the case of health-related issues or when the consumer has had a bad experience with a particular type of food or in a particular restaurant. Another important aspect to exclude alternatives is location, with some consumers not being prepared to travel long distances. Set construction is also based on expectations of a previous satisfactory experience with a particular type of restaurant.

With regard to the evaluation of alternatives and, in particular, sensitivity to evaluative content, the research seems to have shown evidence of the regulatory focus theory of Tuan-Pham and Higgins (2005) in the decision of selecting a restaurant. Arguably, the aspect of restaurant or green consumerism may not only affect their inclusion in the consideration set but may also be considered as part of the states of promotion and prevention that can be endogenously activated. For example, avoiding a restaurant with etiquette restrictions may be part of the evaluation of alternatives; or the selection of a restaurant, through promotion of a "green" restaurant, may play a role in its evaluation and final selection as well.

\section{CONCLUSIONS, LIMITATIONS AND AREAS FOR FURTHER RESEARCH}

The paper makes a number of contributions to our understanding and knowledge of consumer decision making of selecting a restaurant for leisure. The first is the refinement and adaptation of the stylized EKB model for understanding the different stages and features of the decision to select a restaurant. The first three stages: problem/need recognition, information search and consideration set formation, were labeled "antecedents". The stages "evaluation of alternatives" and "choice" are related to the choices that consumers make when selecting a restaurant. These are called "choice considerations". Choice 
considerations refer to how alternatives are evaluated, and aspects such as the decision rules that consumers apply when making the decision are part of those considerations. The aspect of "choice" requires further development; for that reason, it is beyond the scope of this paper and is clearly an area for further research. Choice considerations are connected with the aspect of restaurant attributes, although in the model it is acknowledged that choices could be made not only on the basis of attributes but also based on alternatives (i.e. type of cuisine) or on considerations such as green consumerism or restaurant etiquette. This paper has the purpose of providing a road map for further investigation of the consumer decision, and does not intend to be comprehensive as covering all these processes in a single paper is deemed impossible. Therefore, post-choice processes are not considered here but they nevertheless represent a rich and important area for further research. The second important contribution is the finding of the centrality of occasion for understanding the selection of a restaurant by consumers. This seems particularly important for segmenting markets. This, in turn, leads to the conclusion that different occasions may lead to different strategies for information search. The choice can be shifted from alternative-based to attribute-based, and the importance of attributes may vary according to the occasion, e.g. anniversary, birthday, just to name a few of the influences of occasion on the decision. Thirdly, the findings show that attribute information has a greater weight on how the alternative is evaluated, confirming Tuan-Pham and Higgins (2005) theory. Finally, managers should understand that, according to regulatory focus theory, consumers who are prevention-focused actively avoid restaurants that trigger the idea of aspects like allergies, noise or dress codes. Likewise, some consumers (promotionfocused) are attracted to restaurants that highlight aspects like authenticity or green consumerism.

The proposal of the Consumer Decision Process using the stylized EKB model can serve as a framework for a thorough evaluation of aspects of the decision, even for other contexts. Nonetheless, the paper acknowledges its limitations, i.e. the findings are based on focus groups that consist of a small number of participants. It is possible that a larger number of focus group interviews would have shed more light on the various aspects of the consumer decision in selecting a restaurant. Furthermore, it could be argued that a single geographic location can limit the conclusions drawn. It is also acknowledged that the individual's situation, in terms of frequency for eating out for leisure and money available to spend, may be factors that affect decision making; hence, their involvement in the decision may also differ. However, it should be noted that London and the South-East of the UK have a high concentration of restaurants; it is one of the most vibrant regions of the world with almost every type of cuisine available and where people eat out very regularly.

\section{References}

1. Alonso-López, M. (2016). The Role of Emotions in the Consumer: Theoretical Review and Analysis of Components. International Journal of Social, Behavioral, Educational, Economic, Business and Industrial Engineering, 10(3), 890-894.

2. Ashman, R., Solomon, M. R., \& Wolny, J. (2015). An old model for a new age: Consumer decision making in participatory digital culture. Journal of Customer Behavior, 14(2), 127-146.

3. Bagozzi, R. P, Gopinath, M., \& Nyer, P. U. (1999). The role of emotions in marketing. Journal of the Academy of Marketing Science, 27(2), 184-206.

4. Bartels, D. M., \& Johnson, E. J. (2015). Connecting cognition and consumer choice. Cognition, 135, 47-51. 
5. Bazeley, P., \& Jackson, K. (2013). Qualitative Data Analysis with Nvivo. $2^{\text {nd }}$ edition. London: Sage.

6. Bei, L. T., Chen, E. Y., \& Widdows, R. (2004). Consumers' online information search behavior and the phenomenon of search vs. experience products. Journal of Family and Economic Issues, 25(4), 449-467.

7. Belk, R. W. (1975). Situational Variables and Consumer Behavior. Journal of Consumer Research, 2(3), 157-164.

8. Bertaux, D. (1981). From the life-history approach to the transformation of sociological practice. In: D. Bertaux (ed.). Biography and society: The life history approach in the social sciences (pp. 29-45), London: Sage.

9. Bettman, J. R. (1979). An information processing theory of consumer behavior. Reading (MA): Addison-Wesley.

10. Blackwell, R. D., Miniard, P. W., \& Engel, J. F. (2006). Consumer Behavior. 10 $0^{\text {th }}$ edition. Mason, OH: Thomson.

11. Bone, P. F. (1995). Word of Mouth Effects on Short-Term and Long-Term Product Judgments. Journal of Business Research, 32(3), 213-223.

12. Bray, J. (2008). Consumer Behavior Theory: Approaches and Models. Available at: http://eprints. bournemouth.ac.uk/10107/1/ (March 16, 2015)

13. Bristol, T. F., \& Fern, E. F. (1996). Exploring the atmosphere created by focus group interviews: Comparing consumers' feelings across qualitative techniques. Journal of the Market Research Society, 38(2), 185-195.

14. Bruner, G. C., \& Pomazal, R. J. (1988). Problem recognition: the crucial first stage of the consumer decision process. Journal of Consumer Marketing, 5(1), 53-63.

15. Bryman, A. (2008). Social Research Methods. $3^{\text {rd }}$ edition. Oxford: Oxford University Press.

16. Chen, Z., \& Dubinsky, A. J. (2003). A conceptual model of perceived customer value in e-commerce: A preliminary investigation. Psychology \& Marketing, 20(4), 323-347

17. Clark, M. A., \& Wood, R. C. (1998). Consumer loyalty in the restaurant industry - a preliminary exploration of the issues. International Journal of Contemporary Hospitality Management, 10(4), 139-144.

18. Davis, F. D., \& Warshaw, P. R. (1991). Choice Sets and Choice Intentions. The Journal of Social Psychology, 131(6), 823-830.

19. Di-Cicco-Bloom, B., \& Crabtree, B. F (2006). The Qualitative Research Interview. Medical Education, 40, 314-321.

20. Einhorn, H. J., \& Hogarth, R. M. (1981). Behavioral Decision Theory: Processes of judgment and Choice. Annual review of Psychology, 32, 53-88.

21. Engel, J. F., Kollat, D. T., \& Blackwell, R. D. (1973). Consumer Behavior. $2^{\text {nd }}$ edition. New York, NY: Holt, Rinehart and Winston, Inc.

22. Erasmus, A. C., Boshoff, E., \& Rousseau, G. G. (2001). Consumer decision-making models within the discipline of consumer science: a critical approach. Journal of Family Ecology and Consumer Sciences, 29(1), 82-90.

23. Fern, E. F. (1982). The Use of Focus Groups for Idea Generation: the effects of Group Size, Acquaintanceship, and Moderator on Response Quantity and Quality. Journal of Marketing Research, 19(1), $1-13$.

24. Firat, A. F., \& Venkatesh, A. (1995). Liberatory postmodernism and the reenchantment of consumption. Journal of consumer research, 22(3), 239-267.

25. Fisk, R. P. (1981). Toward a consumption/evaluation process model for services. In: J. H. Donnelly \&W. R. George (eds). Marketing of services (pp. 191-195), Chicago, IL: AMA. 
26. Granovetter, M. (1985). Economic action and social structure: the problem of embeddedness. American Journal of Sociology, 91(3), 481-510.

27. Green, J., \& Thorogood, N. (2004). Qualitative methods for health research. $2^{\text {nd }}$ edition. Thousand Oaks, CA: Sage.

28. Greenbaum, T. L. (1988). The Practical Handbook and Guide to Focus Group Research. Lexington, MA: Lexington Books.

29. Hauser, J. R. (2014). Consideration-set heuristics. Journal of Business Research, 67(8), 1688-1699.

30. Hauser, J. R., \& Wernerfelt, B. (1990). An evaluation cost model of consideration sets. Journal of Consumer Research, 16(4), 393-408.

31. Herr, P. M., Kardes, F. R., \& Kim, J. (1991). Effects of word-of-mouth and product-attribute information on persuasion: An accessibility-diagnosticity perspective. Journal of Consumer Research, 17(4), 454-462.

32. Higgins, E. T. (1997). Beyond Pleasure and Pain. American Psychologist, 52(12), 1280-1300.

33. Higgins, E. T. (1998). Promotion and Prevention: regulatory focus as a motivational principle. In: M. P. Zanna (ed.). Advances in Experimental Psychology (pp. 1-46), San Diego, CA: Academic Press.

34. Higgins, E. T. (2002). How Self-Regulation Creates Distinct Values: The Case of Promotion and Prevention Decision Making. Journal of Consumer Psychology, 12(3), 177-191

35. Hong, I. B. (2015). Understanding the consumer's online merchant selection process: The roles of product involvement, perceived risk, and trust expectation. International Journal of Information Management, 35(3), 322-336.

36. Howard, J. A., \& Sheth, J. N. (1969). The theory of buyer behavior. New York, NY: John Wiley \& Sons.

37. Hoyer, W. D., \& MacInnis, D. J. (2003). Consumer Behavior. $3^{\text {rd }}$ edition. Boston, MA: Houghton Mifflin.

38. Jasinka, A. J., Ramamoorthy, A., \& Crew, C. M. (2011). Toward a Neurobiological Model of Cue-Induced Self-Control in Decision Making: Relevance to Addiction and Obesity. The Journal of Neuroscience, 31(45), 16139-16141.

39. Johar, G. V., Maheswaran, D., \& Peracchio, L. A. (2006). Mapping the frontiers: Theoretical advances in consumer research on memory, affect, and persuasion. Journal of Consumer Research, 33(1), 139-149.

40. Johnson, A. R., \& Stewart, D. W. (2005). A reappraisal of the role of emotion in consumer behavior: traditional and contemporary approaches. In: N. K. Malhotra (ed.). Review of Marketing Research (pp. 1-30), Armonk, NJ: Sharpe.

41. June, L. P., \& Smith, S. L. J. (1987). Service Attributes and Situational Effects on Customer Preferences for Restaurant Dining. Journal of Travel Research, 26(2), 20-27.

42. Kahneman, D. (1991). Judgment and decision-making a personal view. Psychological Science, 2(3), 142-145.

43. Khan, U., Dhar, R., \& Wertenbroch, K. (2005). A Behavioral decision theory perspective on hedonic and utilitarian choice. In: S. Ratneshwar \& D. G. Mick (eds.). Inside Consumption - Consumer motives, goals and desires (pp. 144-165), Abingdon, NY: Routledge.

44. Kivela, J. J. (1997). Restaurant marketing: selection and segmentation in Hong Kong. International Journal of Contemporary Hospitality Management, 9(3), 116-123.

45. Krishna, A., \& Schwartz, N. (2014). Sensory marketing, embodiment, and grounded cognition: Implications for consumer behavior. Journal of Consumer Psychology, 24(2), 159-298.

46. Krishnamurti, T., Schwartz, D., Davis, A., Fischhoff, B., de Bruin, W. B., Lave, L., \&Wang, J. (2012). Preparing for smart grid technologies: A behavioral decision research approach to understanding consumer expectations about smart meters. Energy Policy, 41, 790-797.

47. Lerner, J. S., Li, Y., Valdesolo, P., \& Kassam, K. S. (2015). Emotion and Decision Making: Online Supplement. Annual. Review of Psychology, 66, 33-1. 
48. Loewenstein, G., \& Lerner, J. S. (2003). The role of affect in decision making. Handbook of affective science, $619,3$.

49. Longart, P. (2010). What drives word of mouth in restaurants?. International Journal of Contemporary Hospitality Management, 22(1), 121-128.

50. Lutz, R. J., \& Reilly, P. J. (1974). An Exploration of the Effects of Perceived Social and Performance Risk on Consumer Information Acquisition. In: S. Ward \& P. Wright (eds.). Advances in Consumer Research (pp. 393-405), Provo, UT: Association for Consumer Research.

51. Marshall, M. N. (1996). Sampling for qualitative research. Family practice, 13(6), 522-526.

52. Mehta, S. S., \& Maniam, B. (2002). Marketing Determinants of Customers' Attitudes towards Selecting a Restaurant. Academy of Marketing Studies Journal, 6(1), 27-44,

53. Milner, T., \& Rosenstreich, D. (2013). A review of consumer decision-making models and development of a new model for financial services. Journal of Financial Services Marketing, 18(2), 106-120.

54. Mizerski, R. W. (1982). An Attributional Explanation of the Disproportionate Influence of Unfavourable Information. Journal of Marketing Research, 38(1), 131-142.

55. Morgan, D. (1996). Focus groups. Annual Review Sociology 22, 129-152.

56. Nicosia, F. M. (1966). Consumer Decision Processes: Marketing and Advertising Implications. Englewood Cliffs: Prentice-Hall.

57. O'Shaughnessy, J. (2003). The Marketing Power of Emotion. Oxford: Oxford University Press.

58. Olshavsky, R. W., \& Granbois, D. H. (1979). Consumer decision making-fact or fiction?. Journal of Consumer Research, 6(2), 93-100.

59. Pankajakshi, R., \& Savitha-Rani, R. (2015). Consumer decision-making process models: A comparative study. International Journal of Management and Social Science Research Review, 1(10), 157-168.

60. Pantelidis, I. S. (2010). Electronic Meal Experience: A Content Analysis of Online Restaurant comments. Cornell Hospitality Quarterly, 51(4), 483-491.

61. Payne, J. W., Bettman, J. R., \& Johnson, E. J. (1993). The Adaptive Decision Maker. Cambridge: Cambridge University Press.

62. Rickwood, C., \&White, L. (2009). Pre-purchase decision-making for a complex service: retirement planning. Journal of Services Marketing, 23(3), 145-153.

63. Ritchie, J., Lewis, J., McNaughton-Nicholls, C., \& Ormston, R. (2014). Qualitative Research Practice. $2^{\text {nd }}$ edition. London: Sage.

64. Roberts, J., \& Nedungadi, P. (1995). Studying Consideration in the Consumer Decision Process: Progress and Challenges. International Journal of Marketing, 12(1), 3-7.

65. Smith, C. A., \& Ellsworth, P. C. (1985). Patterns of cognitive appraisals in emotions. Journal of Personality and Social Psychology, 48(4), 813-838.

66. Soscia, I. (2007). Gratitude, Delight, or Guilt: The role of Consumers' Emotions in Predicting Post-consumptions behaviors. Psychology \& Marketing, 24(10), 871-904.

67. Sparks, B. A., Bradley, G. L., \& Callan, V. J. (1997). The impact of staff empowerment and communication style on customer evaluations: The special case of service failure. Psychology \& Marketing, 14(5), 475-493.

68. Statt, D. A. (1997). Understanding the consumer: A psychological approach. London: Palgrave.

69. Strauss, A., \& Corbin, J. (1998). Basics of qualitative research: Techniques and procedures for developing grounded theory. Thousand Oaks, CA: Sage.

70. Thaler, R. (1980). Toward a Positive Theory of Consumer Choice. Journal of Economic Behavior and Organization, 1(1), 39-60.

71. Threlfall, K. D. (1999). Using focus groups as a consumer research tool. Journal of Marketing Practice: Applied Marketing Science, 5(4), 102-105. 
72. Tuan-Pham, M., \& Higgins, E. T. (2005) Promotion and prevention in consumer - the state of the art and theoretical propositions. In: S. Ratneshwar \& D. G. Mick (eds.). Inside Consumption - Consumer motives, goals and desires (pp. 8-43), Abingdon, NY: Routledge.

73. Wangenheim, F. V. (2005). Postswitching negative word of mouth. Journal of Service Research, $8(1), 67-78$

74. Warde, A. (2014). After taste: Culture, consumption and theories of practice. Journal of Consumer Culture, 14(3), 279-303.

75. Watson, L., \& Spence, M. T. (2007). Causes and consequences of emotions on consumer behaviour - a review and integrative cognitive appraisal theory. European Journal of Marketing, 41(5/6), 487-511.

76. Wilkie, W. L. (1994). Consumer Behavior. New York, NY: Van Hoffman Press.

77. Zajonc, R. B. (1980). Feeling and thinking: Preferences need no Inferences. American Psychologist, 35(2), 151-175.

78. Zajonc, R. B. (1984). On the Primacy of Affect. American Psychologist, 39(2), 117-123. 